\title{
Hydrochemical Characteristics, Plant Nutrients and Metals in Household Greywater and Soils in Homa Bay Town
}

\author{
Francis W. Kariuki*, Victor G. Ng`ang`a and Kiplagat Kotut
}

Kenyatta University, Department of Plant and Microbial Science, P.O. Box 43844 Nairobi, Kenya

\begin{abstract}
Greywater recycling has been identified as an efficient method to conserve water. The purpose of this study was to investigate some selected hydrochemical characteristics, plant nutrients and metal content of greywater and soils in residential areas of Homa Bay town. Laundry greywater had the highest $\mathrm{pH}(9.1 \pm 0.01)$, Electrical conductivity $(2900 \pm$ $\left.215 \mu \mathrm{S} \mathrm{cm}^{-1}\right)$ and salinity $\left(0.4 \pm 0.02-0.8 \pm 0.01 \mathrm{mg} \mathrm{L}^{-1}\right)$. The lowest electrical conductivity $\left(400 \pm 50 \mu \mathrm{S} \mathrm{cm}{ }^{-1}\right) \mathrm{was}^{2}$ recorded in bathing greywater. The highest SAR $(4.63 \pm 0.23)$ was recorded in laundry gerywater from non-sewered households and the lowest SAR $(0.72 \pm 0.12)$ in kitchen greywater from sewered households. The SAR values of greywater in Homa Bay were lower than the acceptable limit of 6 for moderate restriction on the use of such water for irrigation. The SAR values for soils in Homa Bay were $2.12 \pm 0.13$ and $4.21 \pm 0.11$ in soils that had received kitchen and bathing greywater respectively and $27 \pm 0.5$ for rainfed soil. Nitrogen, Phosphorus, Sodium, Iron, Copper, Cadmium and Chromium concentration were highest in laundry greywater. The highest values of Zinc and Manganese were in kitchen greywater from non-sewered households. Levels of metals in soils that had been exposed to greywater were lower than the recommended limits. A significant $(\mathrm{p}<0.05)$ positive correlation was recorded between concentration of $\mathrm{Cd}$ in bathing greywater and in the soil. A significant $(\mathrm{p}<0.05)$ negative correlation between the concentration of $\mathrm{Cu}$ in kitchen greywater and in soils was also recorded.
\end{abstract}

Keywords: Greywater, hydrochemical, macronutrients, micronutrients, heavy metals, soil.

\section{INTRODUCTION}

In many parts of the world, water scarcity is one of the most significant challenges to human health and environmental integrity. Some regions are faced with acute physical water scarcity (Middle East, North Africa, parts of South Asia, China, Australia and Latin America) while others are challenged by economic water scarcity (much of Africa, parts of India) [1]. As the world's population grows and the standard of living goes up, demand for water will increase without the possibility for an increase in supply. The mounting demand on this finite and invaluable resource, coupled with its scarcity in many areas of the world, and environmental problems associated with wastewater disposal, has inspired creative strategies for freshwater management, including innovative techniques for wastewater recycling. Reclaiming wastewater is increasingly recognized as an essential strategy to augment water supplies that are under pressure in many areas of the world. One such strategy is the reuse of greywater which comprises $55-75 \%$ of all household wastewater [2].

The most commonly described reuse of greywater is for toilet/urinal flushing which can reduce water demand within

*Address correspondence to this author at the Kenyatta University, Department Of Plant and Microbial Science, P.O. Box 43844 Nairobi, Kenya; Tel: 0721457747; Fax: +254-020-811575/811242;

E-mails: franciskrk@yahoo.com or francis.kariuki2@gmail.com households by up to $30 \%$ [3]. Greywater has also been considered for many other applications including irrigation of lawns and golf courses [4], vehicle washing, fire protection, boiler feed water, concrete production [5] and preservation of wetlands [6]. However, the major drawbacks for all the potential alternatives mentioned above are the risks related to handling and exposure to greywater. Although globally greywater is produced from similar household activities, its composition differs between households and, regions [7, 8]. These differences are caused mainly by the variation in chemicals used in households and hygiene practices, the inhabitants per household and the density and type of buildings in the settlement $[7,8]$, the type of pipes used for transportation and the quality of the water supply when it leaves the water works [9].

Greywater reuse without treatment in rural and densely populated peri-urban communities is a common practice [10, $11,7]$. However, greywater reuse without prior treatment can pose a health risk [12]. A recent study has demonstrated that the bacterial load of greywater could be reduced to levels suitable for non-potable applications using a low cost greywater treatment system [13]. However, health risks to humans will differ from site to site and the management of greywater generated will, therefore, have to be tailored to site-specific conditions.

Although the contribution of greywater to alleviating water scarcity is limited, it can be a strategy to alleviate poverty 


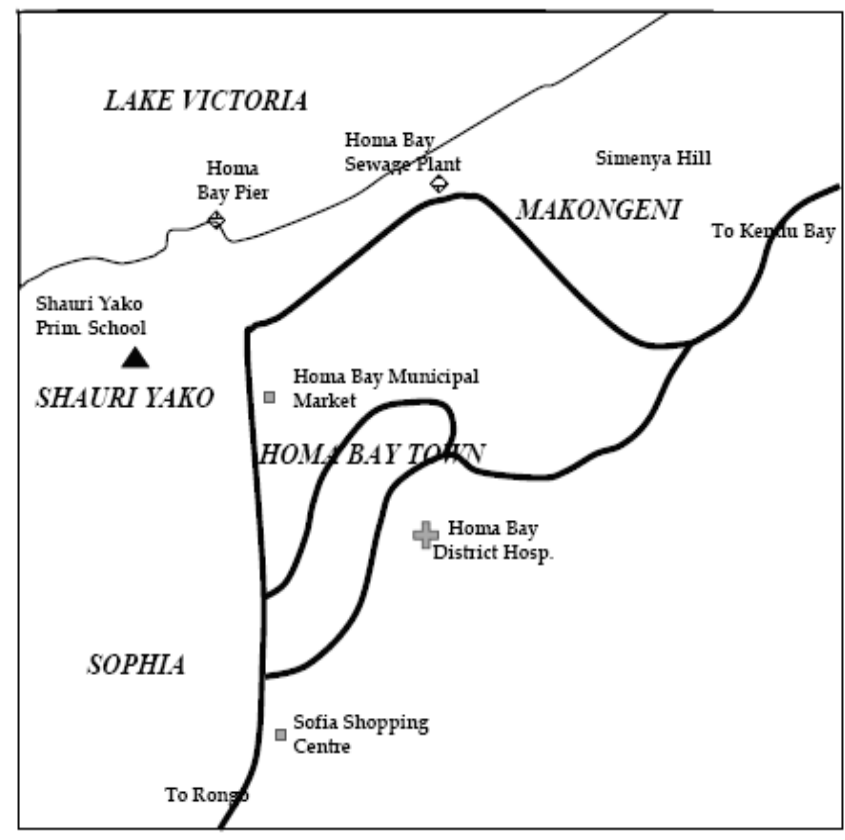

Fig. (1). Map of Homa Bay Town showing the sampling sites [12].

by providing a source of irrigation water to household or multi-household agricultural production [2]. Experiences with greywater reuse for irrigation have demonstrated a general net benefit in terms of water conservation, reduction in strain on wastewater facilities, food production, and aquifer recharge [14]. Although conceived to be "clean," its reuse is however not without its hazards since it may contain organic and chemical compounds that can pollute the environment and pose a health risk to humans [15-17]. With respect to irrigation, the most prevalent risks are those associated with elevated $\mathrm{pH}$, salinity, and boron in greywater and the potential accumulation of pathogens, metals, and organic chemicals in receiving soils. The first three factors affect mainly soil properties while the latter three can have implications for human health, especially in the irrigation of edible crops [10].

A number of studies have been conducted to characterize domestic greywater [7, 9, 17-19]. Available information on the characteristics of greywater is mainly on the content of organic matter (BOD/COD), nutrients ( $, \mathrm{P}, \mathrm{K})$ and microorganisms [7]. However, greywater also contains metallic ion pollutants due to the detergents used in laundry, dishwashing and bathing soaps and to cosmetic and body lotions used [20]. To date, risk assessment of potential for greywater reuse has focused almost exclusively on pathogenic microorganisms and conventional water quality parameters. Information on the presence of metals in various types of greywater such as bathroom, kitchen and laundry, is currently limited to a handful of studies [7]. It is important to have a general characterization of greywater since the different parameters will have different impacts on human health and the terrestrial, aquatic, and agricultural environment. This paper presents baseline results of selected hydrochemical characteristics, plant nutrients and metal content of greywater and soils in residential areas of Homa Bay town.

\section{STUDY METHODOLOGY}

Study Site

Homa Bay Town is located along the north - eastern part of Lake Victoria, 105 kilometers South of Kisumu City and 405 kilometers southwest of Nairobi (Fig. 1). The town has several residential estates including Sophia, Shauri Yako and Makongeni where this study was conducted. The total area of the municipality is about $197 \mathrm{~km}^{2}$, of which Lake Victoria covers about $97 \mathrm{~km}^{2}$. The town lies on the lake shore lowlands, with an altitude of between 1,143 to 1,220 metres above sea level.

\section{Sample Collection}

\section{a). Water}

Greywater samples were collected from fifteen sewered and non-sewered households each chosen randomly in each visit. Among them, five households of each type provided samples from bathrooms, five from kitchens and five from laundry activities as described in [12]. The samples were collected in 1-litre plastic containers previously cleaned by washing in non-ionic detergent, rinsed with tap water and later soaked in $10 \% \mathrm{HNO}_{3}$ for 24 hours and finally rinsed with deionised water prior to usage. Five water samples each from tap and lake sources were also collected during each visit.

\section{Determination of General Hydrochemical Parameters}

Electrical conductivity (EC), $\mathrm{pH}$ and salinity and turbidity of greywater were measured in-situ directly in the field using a WTW Multiline P4 meter (Weilheim, Germany) and a Hach 2100P portable turbidity meter respectively. Both field meters were checked and calibrated according to the manufacturer's specifications. Thereafter, sample bottles were filled up with source waters and greywater and transported in a cool box to the Horticulture laboratory at the Department of Horticulture in Jomo Kenyatta University of Science and Technology. Analysis of the water samples was carried out as follows:

\section{Total Nitrogen and Phosphorus in Greywater}

Collected samples were analyzed for total nitrogen (TKN) by Kjeldahl Method while the phosphorus concentrations were determined spectrophotometrically using the ascorbic acid reduction procedure [21].

\section{Macronutrients in Greywater}

The water samples were filtered using whatman paper no. 42 and the filtrate topped to $50 \mathrm{mls}$. Both $\mathrm{K}$ and $\mathrm{Na}$ in the filtrate were determined using a flame photometer while $\mathrm{Ca}$ and $\mathrm{Mg}$ in the filtrate were determined using atomic absorption spectrometry (Perkin Elmer; Model Analyst 300).

\section{Micronutrients and Heavy Metals in Greywater}

Cadmium, $\mathrm{Cr}$ and $\mathrm{Pb}$ were extracted using nitric acid while $0.005 \mathrm{M}$ DTPA (diethylene triamine pentaacetic acid) was used to extract $\mathrm{Zn}, \mathrm{Cu}, \mathrm{Fe}$ and $\mathrm{Mn}$ and filtered using whatman paper no. 42. The filtrates obtained were analyzed using an atomic absorption spectrophotometer equipped with a graphite furnace (Perkin Elmer; Model Analyst 300). 


\section{b). Soil}

Soil samples were collected at a depth of $1.30 \mathrm{~cm}$ from designated home gardens irrigated each with bath and kitchen greywater and a reference soil sample that was rainfed for comparison purpose. Four samples were collected from each garden. At each sampling site, surface litter was first scraped away to remove plant debris. Soil analysis was done as follows:

\section{Soil pH and Electrical Conductivity Determination}

The $\mathrm{pH}$ of each soil sample was determined using a calibrated Field scout $\mathrm{pH}$ meter (Spectrum technologies, Inc) in a saturated soil paste (1:5 Soil: water ratio). The electrical conductivity (EC) was also determined using a calibrated Field scout EC meter (Spectrum technologies, Inc) in a saturated soil paste (1:5 soils: water ratio).

\section{Total Nitrogen and Phosphorus in Soil}

Total nitrogen was determined using the Kjeldahl method after nitrates and nitrites were reduced to ammonium with Devarda alloy. Ammonium was determined colorimetrically. Estimation of total phosphorus was done using an automated molybdenum-blue colorimetric procedure.

\section{Macronutrients in Soil}

A soil sample was extracted with an excess of $1 \mathrm{M}$ ammonium acetate solution. Exchangeable $\mathrm{K}, \mathrm{Ca}, \mathrm{Na}$ and $\mathrm{Mg}$ were measured using an atomic absorption spectrophotometer equipped with a graphite furnace (Perkin Elmer; Model Analyst 300).

\section{Micronutrients and Heavy Metals in Soil}

Samples were dried in an oven at $110^{\circ} \mathrm{C}$, sieved through a $2 \mathrm{~mm}$ sieve to remove extraneous materials, and retained for further analysis. The micronutrients $\mathrm{Zn}, \mathrm{Mn}, \mathrm{Cu}$ and $\mathrm{Fe}$ and the heavy metals $\mathrm{Pb}, \mathrm{Cd}$ and $\mathrm{Cr}$, in the soil were extracted by using $20 \mathrm{~g}$ of soil in $40 \mathrm{ml}$ of $0.005 \mathrm{M}$ DTPA solution. The Extractable metals ( $\mathrm{Pb}, \mathrm{Zn}, \mathrm{Mn}, \mathrm{Cu}, \mathrm{Fe}, \mathrm{Cr}$, and $\mathrm{Cd})$ in the resulting solutions were determined using Atomic Absorption Spectrophotometer equipped with graphite furnace (Perkin Elemer Model Analyst 300).

\section{Sodium Adsorption Ratio (SAR)}

Calcium, magnesium and sodium concentrations (mmol $\mathrm{L}^{-1}$ ) were used to calculate the sodium adsorption ratio (SAR), defined as [22]:

$$
S A R=\frac{\left[\mathrm{Na}^{+}\right]}{\sqrt{\frac{1}{2}\left(\left[\mathrm{Ca}^{2+}\right]+\left[\mathrm{Mg}^{2+}\right]\right)}}
$$

\section{Statistical Analysis}

A one way Analysis of variance (ANOVA) was carried out to test the difference in plant nutrients and metals among the greywater sources and soils while simple correlation analysis was performed to assess the relationship between the metal content in greywater and in the soil.

\section{RESULTS AND DISCUSSION}

\section{Hydrochemical Characteristics of Greywater and Soil}

Irrespective of type or source, laundry greywater had the highest $\mathrm{pH}(9.1 \pm 0.01)$, EC $\left(2900 \pm 215 \mu \mathrm{S} \mathrm{cm}^{-1}\right)$ and salinity $\left(0.4 \pm 0.02-0.8 \pm 0.01 \mathrm{mg} \mathrm{L}^{-1}\right)$ while the lowest EC (400 $\pm 50 \mu \mathrm{S} \mathrm{cm}^{-1}$ ), salinity (below detection limit) were observed in bathing greywater (Fig. 2). In terms of SAR, the highest value $(4.63 \pm 0.23)$ was recorded in laundry greywater from non-sewered households and the least $(0.72 \pm 0.12)$ in Kitchen greywater from sewered households, while SAR values of $0.31 \pm 0.02$ and $0.28 \pm 0.01$ were recorded in tap and lake water respectively (Fig. 2). The $\mathrm{pH}$ for both bathing and kitchen greywater was near neutral (Fig. 2).

The $\mathrm{pH}$ of soil irrigated with greywater ranged from 5.58 \pm 0.01 to $7.9 \pm 0.014$ for bathing and kitchen greywater respectively (Fig. 3). Soil under rainfed had similar $\mathrm{pH}$ to that irrigated with kitchen or laundry greywater. Soil irrigated with bathing greywater had significantly $(\mathrm{p}<0.05)$ lower $\mathrm{pH}$ than that of soil irrigated with kitchen or laundry greywater. The highest EC value of $1300 \pm 150 \mu \mathrm{S} \mathrm{cm}^{-1}$ was recorded in soils that were irrigated with kitchen and bathing greywater and least $\left(300 \pm 60 \mu \mathrm{S} \mathrm{cm}^{-1}\right)$ in rainfed soil while a middle value of $660 \pm 57 \mu \mathrm{S} \mathrm{cm}^{-1}$ was recorded in soils irrigated with laundry greywater (Fig. 3). The calculated SAR values for soils in Homa Bay were $2.12 \pm 0.13$ and $4.21 \pm 0.11$ for soils that had received kitchen and bathing greywater respectively and $27 \pm 0.5$ for the rainfed soil.

In a similar set up in Nakuru Town, pH, EC and salinity were also highest in laundry greywater and least in kitchen greywater [23]. Lack of variation in the $\mathrm{pH}$, salinity and electrical conductivity of greywater across the geographical areas in Kenya suggests that the cleaning agents (soaps and detergents) used may have been the same or their contents were similar. The high $\mathrm{pH}$ values of the laundry greywater could be attributed to the alkalinity of the detergents and or soaps that are typically used [24].

The major concerns surrounding greywater reuse in agriculture with regard to soil are salinity and sodicity, both of which are related to the concentration of sodium in greywater $[25,26]$. Sodium adsorption ratio (SAR) is an index of the ratio of sodium concentration (detrimental element) to calcium and magnesium (beneficial elements) concentration [27]. The SAR levels in greywater are typically within the range 2 to 10 depending on the source of greywater [28]. The greywater SAR values in Homa Bay were lower than the acceptable upper SAR limit of 6 for slight to moderate restriction on the use of such water for irrigation [29]. The SAR results for Homa Bay are similar to those of Uganda where the highest SAR among greywater types was recorded in laundry greywater with least in dish greywater [30] and both confirms that laundry greywater is the least suitable for irrigating sensitive crops, mainly due to its high sodium concentrations and a high $\mathrm{pH}$ [31]. Since the EC and SAR values of the soils samples that had been receiving greywater were with the allowable limits, irrigation with greywater generated in Homa Bay may not affect the soil structure at least in the short term but there is need to investigate the effect of long-term irrigation. 

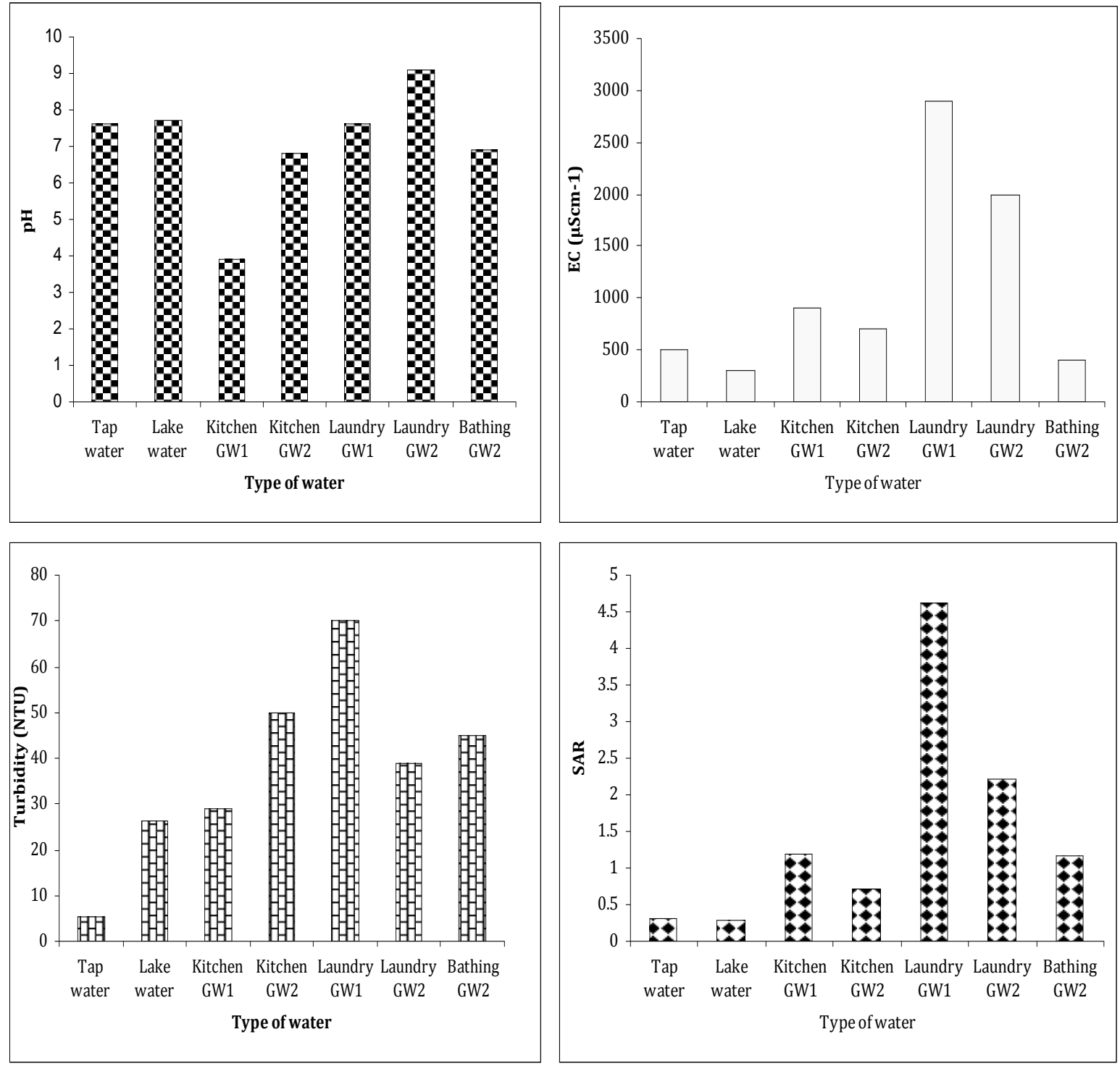

Fig. (2). Mean levels of some hydrochemical characteristics of source waters and greywater types from households in Homa Bay town. KEY

GW1-non sewered households

GW2 -sewered households
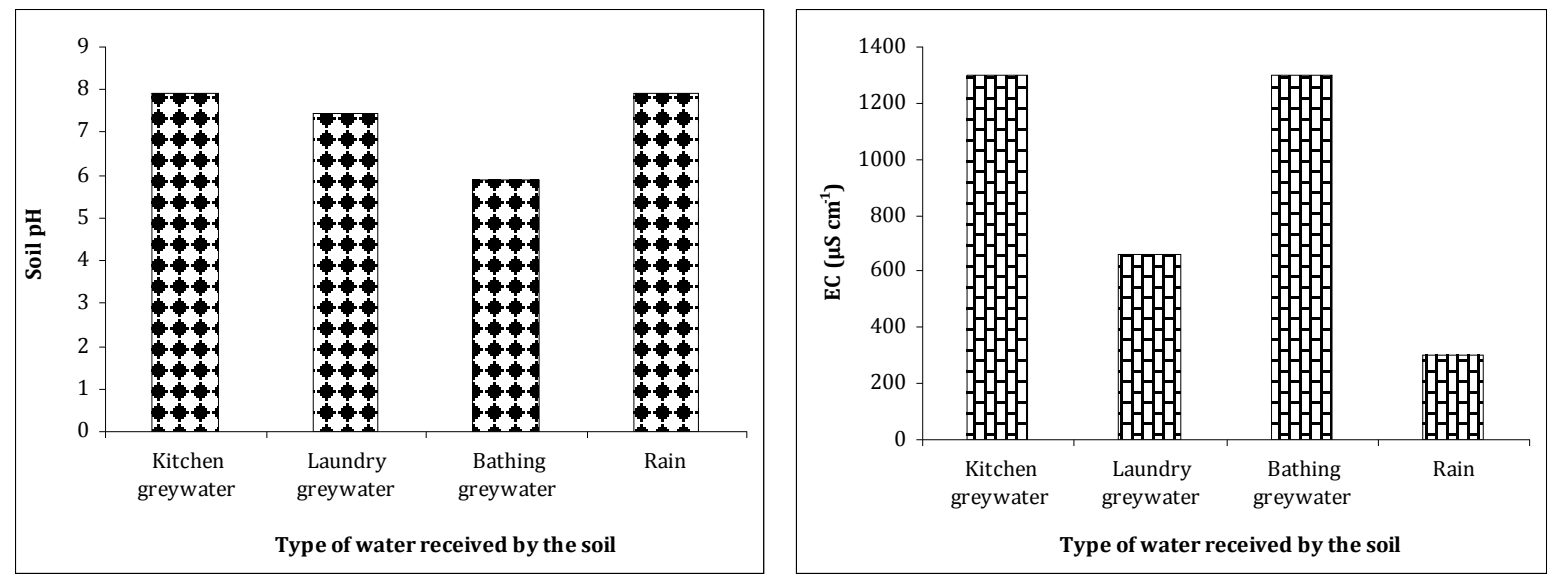

Fig. (3). Mean $\mathrm{pH}$ and EC of soils receiving different types of greywater from households in Homa Bay town. 
Table 1. Mean Plant Nutrients and Metal Concentration in Source Waters and Greywater Types from Households and Soils in Homa Bay Town and Limits Set by [40] Guidelines for Irrigation with Wastewater

\begin{tabular}{|c|c|c|c|c|c|c|c|c|c|c|c|c|c|}
\hline & \multirow{2}{*}{ units } & \multirow{2}{*}{ Tap water } & \multirow{2}{*}{ Lake water } & \multirow{2}{*}{$\begin{array}{l}\text { Non-sewered } \\
\text { kitchen GW }\end{array}$} & \multirow{2}{*}{$\begin{array}{l}\text { Non-sewrered } \\
\text { laundry GW }\end{array}$} & \multirow{2}{*}{$\begin{array}{l}\text { Sewered } \\
\text { bath GW }\end{array}$} & \multirow{2}{*}{$\begin{array}{c}\text { Sewered } \\
\text { kitchen GWz }\end{array}$} & \multirow{2}{*}{$\begin{array}{c}\text { Sewered } \\
\text { laundry GW }\end{array}$} & \multirow{2}{*}{$\begin{array}{l}\text { Soil hitchen } \\
\text { GW }\end{array}$} & \multirow{2}{*}{$\begin{array}{l}\text { Soil bath } \\
\text { GW }\end{array}$} & \multirow{2}{*}{$\begin{array}{c}\text { Rainfed Soil } \\
\text { (Control) }\end{array}$} & \multicolumn{2}{|c|}{$\begin{array}{c}\text { Limits for irrigation } \\
\text { using wastewater [40] }\end{array}$} \\
\hline & & & & & & & & & & & & $\begin{array}{l}\text { Long- } \\
\text { Term use }\end{array}$ & $\begin{array}{l}\text { Short- } \\
\text { Term use }\end{array}$ \\
\hline $\mathrm{N}$ & $\mathrm{mg} \mathrm{L}^{-1}$ & $28.48 \pm 0.81$ & $8.87 \pm 0.81$ & $6.07 \pm 0.81$ & $12.14 \pm 0.81$ & $11.21=1.40$ & $13.07 \pm 0.81$ & $49.02 \pm 0.00$ & $10.2 \pm 0.00$ & $3.3 \pm 0.00$ & $0.9 \pm 0.00$ & & \\
\hline P & $\mathrm{mg} \mathrm{L}^{-1}$ & $114.09=0.00$ & $124.99 \pm 0.00$ & $173.73 \pm 0.18$ & $278.08 \pm 0.08$ & $69.22 \pm 0.15$ & $323.41 \pm 0.09$ & $704.44 \pm 0.00$ & $242.18 \pm 0.29$ & $169.6 \pm 0.15$ & $37.03 \pm 0.14$ & & \\
\hline $\mathrm{K}$ & $\mathrm{mg} \mathrm{L}^{-1}$ & $7.9 \pm 0.00$ & $11.5=0.00$ & $23.4 \pm 0.00$ & $26.9 \pm 0.00$ & $10 \pm 0.00$ & $16.9 \pm 0.00$ & $31.8 \pm 0.00$ & $10.20 \pm 0.00$ & $3.30 \pm 0.00$ & $0.90=0.00$ & & \\
\hline $\mathrm{Na}$ & $\mathrm{mg} \mathrm{L}^{-1}$ & $4.6 \pm 0.01$ & $3.85=0.00$ & $15.38 \pm 0.00$ & $39.23 \pm 0.00$ & $6.15 \pm 0.00$ & $9.89=0.00$ & $35.38 \pm 0.00$ & $77.7 \pm 0.00$ & $200 \pm 0.00$ & $200 \pm 0.00$ & & \\
\hline $\mathrm{Mg}$ & $\mathrm{mg} \mathrm{L}^{-1}$ & $5.54 \pm 0.22$ & $5.25=0.03$ & $4.8 \pm 0.02$ & $2.54 \pm 0.04$ & $0.27 \pm 0.00$ & $0.28 \pm 0.00$ & $1.14 \pm 0.00$ & $4.32 \pm 0.04$ & $1.60 \pm 0.03$ & $0.01=0.00$ & & \\
\hline $\mathrm{Ca}$ & $\mathrm{mg} \mathrm{L}^{-1}$ & $7.3 \pm 0.19$ & $5.6 \pm 0.02$ & $4.9 \pm 0.07$ & $1.3 \pm 0.01$ & $0.96 \pm 0.04$ & $0.93 \pm 0.00$ & $0.32 \pm 0.00$ & $2.32 \pm 0.7$ & $1.28 \pm 0.00$ & $0.20=0.06$ & & \\
\hline $\mathrm{Fe}$ & $\mathrm{mg} \mathrm{L}^{-1}$ & $1.3 \pm 0.001$ & $13.5 \pm 0.4$ & $1.90 \pm 0.04$ & $3.6 \pm 0.05$ & $3.8 \pm 0.00$ & $9.7 \pm 0.3$ & $17.5 \pm 1.4$ & $1.14 \pm 0.01$ & $2.22 \pm 0.03$ & $0.09 \pm 0.00$ & 5 & 20 \\
\hline $\mathrm{Zn}$ & $\mathrm{mg} \mathrm{L}^{-1}$ & $0.1 \pm 0.00$ & $0.3 \pm 0.00$ & $6.6 \pm 0.00$ & $0.4 \pm 0.03$ & $0.2 \pm 0.05$ & $0.1 \pm 0.00$ & $0.7 \pm 0.06$ & $0.16 \pm 0.00$ & $1.29 \pm 0.00$ & $0.0 \pm 0.00$ & 2 & 10 \\
\hline Mn & $\mathrm{mg} \mathrm{L}^{-1}$ & $0.4 \pm 0.00$ & $1.1=0.80$ & $1.4 \pm 0.02$ & $0.4 \pm 0.00$ & $0.3 \pm 0.02$ & $0.2 \pm 0.02$ & $0.3 \pm 0.01$ & $1.75 \pm 0.03$ & $1.15 \pm 0.00$ & $0.01=0.00$ & 0.2 & 10 \\
\hline $\mathrm{Cu}$ & $\mathrm{mg} \mathrm{L}^{-1}$ & $0.7 \pm 0.00$ & $0.4 \pm 0.00$ & $0.9 \pm 0.00$ & $l \pm 0.00$ & $2.6 \pm 0.01$ & $2.3 \pm 0.30$ & $2.9 \pm 0.01$ & $0.07 \pm 0.04$ & $0.07 \pm 0.09$ & $0.0 \pm 0.00$ & 0.2 & 5 \\
\hline $\mathrm{Cd}$ & $\mathrm{mg} \mathrm{L}^{-1}$ & $2.7 \pm 0.12$ & $4.5 \pm 0.3$ & $5.5 \pm 0.14$ & $7 \pm 0.08$ & $10.7 \pm 0.03$ & $10 \pm 0.02$ & $11.2 \pm 0.03$ & $14.2 \pm 0.2$ & $13.7 \pm 0.2$ & $0.6 \pm 0.00$ & 0.01 & 0.05 \\
\hline $\mathrm{Pb}$ & $\mathrm{mg} \mathrm{L}^{-1}$ & $0.8 \pm 0.04$ & $0.8 \pm 0.02$ & $0.9 \pm 0.04$ & $0.8 \pm 0.00$ & $0.2 \pm 0.00$ & $0.3 \pm 0.00$ & $0.00 \pm 0.00$ & $0.09 \pm 0.00$ & $0.09 \pm 0.00$ & $0.0 \pm 0.00$ & 5 & 10 \\
\hline $\mathrm{Cr}$ & $\mathrm{mg} \mathrm{L}^{-1}$ & $4.3 \pm 0.4$ & $7.3 \pm 0.13$ & $16.1 \pm 0.17$ & $0.9 \pm 0.02$ & $11.1 \pm 0.09$ & $11.3 \pm 0.00$ & $16.1 \pm 0.11$ & $4.1 \pm 0.01$ & $3.5 \pm 0.03$ & $3.7 \pm 0.01$ & 0.1 & 1 \\
\hline
\end{tabular}

\section{Plant Nutrients and Metals in Greywater}

The results for plant nutrients and metal content in source water and greywater in Homabay are presented in (Table 1). Unlike wastewater that can contain high concentrations of $\mathrm{N}$, $\mathrm{P}$, and $\mathrm{K}$, only minor quantities of nutrients have been detected in greywater samples, rarely exceeding $5 \mathrm{mg} \mathrm{L}^{-1}[32$, 33]. In this study, nutrients essential for plant growth, namely $\mathrm{N}$ and $\mathrm{P}$, were present in greywater in quantities ranging from $6.07 \pm 0.81$ to $49.02 \pm 0.00$ and from $69.22 \pm$ 0.15 to $704.44 \pm 0.00 \mathrm{mg} \mathrm{L}^{-1}$ respectively (Table 1). In both cases, the highest values were recorded in laundry greywater and least in kitchen and bathing greywater for $\mathrm{N}$ and $\mathrm{P}$ respectively (Table 1).

Analysis of variance (ANOVA) show that, except kitchen greywater from sewered households which had significantly $(\mathrm{p}<0.05)$ lower $\mathrm{P}$ level, all greywater types had significantly $(p<0.05)$ higher $P$ levels than tap water. Similarly, within the same households, laundry greywater had significantly $(\mathrm{p}<0.05)$ higher $\mathrm{P}$ level than kitchen greywater. Also, the $\mathrm{P}$ level in both kitchen and laundry greywater was significantly $(\mathrm{p}<0.5)$ higher in sewered than non-sewered households. $\mathrm{N}$ levels in all greywater types was significantly $(\mathrm{p}<0.05)$ lower than tap water except in laundry which was significantly $(\mathrm{p}<0.05)$ higher than both the tap water and all other types of greywater. Similarly, greywater in the City of Montreal also contain very low levels of N, P, K, and heavy metals [18]. In Germany, dishwashing and laundry detergents were the main sources of phosphorous in greywater while kitchen greywater was the main source of nitrogen in domestic greywater [34]. Washing detergents are the primary source of phosphates found in greywater and wide ranges of nutrients concentrations in greywater have been recorded; for instance, concentration ranges of $0.6-74.0 \mathrm{mg} \mathrm{L}^{-1}$ for total nitrogen and 4.0-14.0 $\mathrm{mg} \mathrm{L}^{-1}$ for total phosphorus depending on the use of detergents with or without phosphate [7].

Generally, the lowest levels of $\mathrm{N}$ are observed in bathroom and laundry greywater [34] while in the present study, it was in kitchen greywater from non-sewered households.
The lower $\mathrm{N}$ in greywater than tap water could be due to absence of organic matter as evidenced by low turbidity $(<50$ NTU) while comparatively higher P levels in greywater than tap water can largely be attributed to the use of phosphatecontaining soaps and detergents within the households. Elsewhere, it has been concluded that owing to the low N, P and $\mathrm{K}$ levels of the greywater, plant growth and productivity are unaffected by the water quality [17]. Hence the low levels of $\mathrm{N}$ and $\mathrm{P}$ in greywater in Homa Bay reinforce the potential of domestic greywater as an alternative irrigation source. However, the greywater had N/P ratio of $<1$ which is far below the N/P ratio of around 10 which would be optimal for nutrient uptake by plants [35]. If this greywater is to be reused for irrigation, an additional source of $\mathrm{N}$ is required. Low concentration of nitrogen in greywater represents the limiting factor, which could lead to a sub-optimal phosphorus uptake. In terms of its treatment, the low nutrients ( $\mathrm{N}$ and $\mathrm{P}$ ) levels in greywater limit the efficiency of biological treatment of greywater [33] and as a result [13] recommends a greywater treatment system that combines physical and chemical in the treatment of greywater.

The amount of metals and organic pollutants in greywater is generally low, with levels of most metals being approximately the same as in a mixed wastewater from a household, but can increase due to addition of environmentally hazardous substances [36]. Generally, except $\mathrm{Mg}$ and $\mathrm{Ca}$, the levels of metals ( $\mathrm{K}, \mathrm{Fe}, \mathrm{Zn}, \mathrm{Cu}, \mathrm{Na}, \mathrm{Cd}$ and $\mathrm{Cr}$ ) analyzed were higher in greywater than tap water while the level of $\mathrm{Pb}$ was similar in all source water and greywater types (Table 1). Sodium, $\mathrm{Fe}, \mathrm{Cu}, \mathrm{Cd}$ and $\mathrm{Cr}$ levels were highest in laundry water from sewered households while $\mathrm{Zn}$ and $\mathrm{Mn}$ were highest in Kitchen water from non-sewered households. Potassium, $\mathrm{Na}, \mathrm{Mg}, \mathrm{Ca}, \mathrm{Zn}$ and $\mathrm{Cr}$ levels were higher in Kitchen water from non-sewered households than the sewered. The levels of all metals analyzed except $\mathrm{Na}, \mathrm{Ca}$ and $\mathrm{Cr}$ were higher in laundry greywater from sewered than nonsewered households. Analysis of variance (ANOVA) show that irrespective of whether the household was sewered or not, levels of $\mathrm{Na}, \mathrm{K}, \mathrm{Fe}, \mathrm{Zn}, \mathrm{Cd}$ and $\mathrm{Cr}$ in all greywater types were significantly $(\mathrm{p}<0.05)$ higher than tap water while lev- 
els of $\mathrm{Na}, \mathrm{K}, \mathrm{Mg}, \mathrm{Zn}, \mathrm{Mn}$ and $\mathrm{Cr}$ in kitchen greyater and $\mathrm{Na}$, $\mathrm{Ca}$ and $\mathrm{Pb}$ in laundry greywater were significantly $(\mathrm{p}<0.05)$ higher in non-sewered than sewered households. At the same time, levels of $\mathrm{Fe}, \mathrm{Cu}$ and $\mathrm{Cr}$, and of $\mathrm{K}, \mathrm{Mg}, \mathrm{Fe}, \mathrm{Zn}, \mathrm{Cd}$ and $\mathrm{Cr}$ in kitchen and laundry greywater respectively were significantly $(\mathrm{p}<0.05)$ higher in sewered than non-sewered households. In Copenhagen, the metal concentrations in greywater were in the same range as have been found in other studies except for the alkali and alkali earth metals, which are higher due to the high levels found in the potable water [36]. In Homa Bay, the levels of the two alkali metals, $\mathrm{K}$ and $\mathrm{Na}$ were present in higher concentration in all greywater types than tap water while the level of the two alkali earth metals, $\mathrm{Mg}$ and $\mathrm{Ca}$, were higher in tap water than in all greywater types (Table 1). This could be an indication that households cleaning agents and tap water were the sources of alkali $(\mathrm{K}, \mathrm{Na})$ and alkali earth metals $(\mathrm{Mg}, \mathrm{Ca})$ respectively.

In laundry greywater, the concentration of all heavy metals analyzed except $\mathrm{Cu}, \mathrm{Pb}$ and $\mathrm{Cr}$ were higher in sewered than non-sewered households and were the same in kitchen greywater apart from the concentration of $\mathrm{Zn}, \mathrm{Mn}$ and $\mathrm{Cr}$. Zinc, $\mathrm{Mn}$ and $\mathrm{Pb}$ concentration remained fairly constant in all source waters and greywater discharges. Notable are the high concentrations of $\mathrm{Fe}, \mathrm{Cu}, \mathrm{Cd}$ and $\mathrm{Cr}$ in both laundry and kitchen greywater from sewered households, $\mathrm{Zn}$ in laundry greywater from both types of households and also $\mathrm{Zn}$ and $\mathrm{Cr}$ in kitchen greywater from non-sewered households. With an exception of $\mathrm{Cd}$ and $\mathrm{Cr}$ concentrations which were above the [37] guidelines, all metals investigated meet the requirement for long term use in irrigation (Table 1).

Metals in greywater originate from the water itself, from corrosion of the pipe system and from dust, cutlery, dyes and shampoos used in the household. The probable source for Fe and $\mathrm{Zn}$ could be leaching from the galvanized steel tanks whereas for copper it could be the plumbing materials. The use of non-corrodable (eg. plastic, fibreglass, etc.) materials for water conveyance and storage are recommended. Since the content of metals in greywater is heavily affected by human behavior, their levels can be kept low by use of environmentally-friendly household chemicals.

\section{Metals in Soil}

The results of metal contents show that even the soils that have been exposed to greywater had lower metal content than the recommended limits (Table 1). However, the levels of $\mathrm{Ca}, \mathrm{Mg}, \mathrm{K}, \mathrm{Mn}, \mathrm{Zn}$ and $\mathrm{Fe}$ in soils that had received bath or kitchen greywater were significantly $(\mathrm{p}<0.05)$ higher than in soils that had not received greywater. There was no significant $(\mathrm{p}>0.05)$ difference in the level of $\mathrm{Cu}, \mathrm{Pb}, \mathrm{Cd}, \mathrm{Cr}$ and $\mathrm{Na}$ in soils receiving greywater and that of the soil that had not. It is however noted that even those soils that had not been exposed to greywater had unusually high content of both $\mathrm{Cd}$ and $\mathrm{Cr}$ and equally, water sources (the tap water and Lake water) also had high content of both metals, indicating that the soils in Homa Bay are naturally rich in these two metals. High cadmium values in Lake Victoria around Homa Bay are attributed to natural sources rather than to anthropogenic sources [38]. Soils differ in their content of Cd, Co,
$\mathrm{Mn}, \mathrm{Ni}$, and $\mathrm{pH}$ depending on climate, soil origin and composition and human activities [39].

There is an insignificant $(\mathrm{p}>0.05)$ positive correlation between the concentration of $\mathrm{Mn}$, and $\mathrm{Fe}$ in kitchen greywater and in the soil while a significant $(\mathrm{p}<0.05)$ negative correlation for $\mathrm{Cu}$ in kitchen greywater was recorded. A significant $(\mathrm{p}<0.05)$ positive correlation coefficient of $\mathrm{Cd}$ was found between bathing greywater and soil while a significant $(\mathrm{p}<0.05)$ negative correlation between concentration of $\mathrm{Pb}$ and $\mathrm{Cr}$ in the same greywater and the soil was recorded. Generally, the concentration of $\mathrm{Na}, \mathrm{Cu}, \mathrm{Cd}, \mathrm{Pb}$ and $\mathrm{Cr}$ in greywater irrigated soils is close to levels in rainfed soils while application of greywater had seemingly enriched the soils in $\mathrm{Mg}, \mathrm{Ca}, \mathrm{Fe}, \mathrm{Zn}, \mathrm{Mn}, \mathrm{K}, \mathrm{N}$ and $\mathrm{P}$.

\section{CONCLUSION}

Greywater quality shows high variability, which is consistent with the wide range of values or the elements analyzed reported in the literature. This variability could be due to factors such as source of water, water use efficiencies of appliances and fixtures, individual habits, products used (soaps, shampoos, detergents), and other site-specific characteristics. A comparison of source water and greywater shows that the source water deteriorates significantly after the first use with an increase in the level of turbidity, $\mathrm{pH}, \mathrm{EC}, \mathrm{SAR}$, $\mathrm{P}, \mathrm{N}$ and some metals ( $\mathrm{Na}, \mathrm{K}, \mathrm{Fe}, \mathrm{Zn}, \mathrm{Cu}, \mathrm{Cd}$ and $\mathrm{Cr}$ ). Since these physical and chemical parameters were high particularly in the laundry greywater, its reuse in irrigation should be approached cautiously. In addition, greywater contains essential nutrients (N and P) in low quantities. Since many laundry products contain large amounts of $\mathrm{Na}$ and almost no $\mathrm{N}, \mathrm{K}, \mathrm{Ca}$ or $\mathrm{Mg}$, greywater has little of the positive attributes of fertilizer and it is best to see it as an alternative source of irrigation water but not a substitute for fertilizers.

\section{CONFLICT OF INTEREST}

None declared.

\section{ACKNOWLEDGEMENTS}

The study was made possible by the funding support of the Lake Victoria Research Initiative (VicRes). Our sincere gratitude is due to the communities in Homa Bay for providing greywater and soil samples, to Mr. Philip Kibet and Ms Rose Nyaboke Min'gate for analyzing the samples, and to Mr. Stephen Gichobi for providing technical support.

\section{REFERENCES}

[1] S. McIlwaine and M. Redwood, "The use of greywater for irrigation of home gardens in the middle east: technical, social and policy issues", Water lines, vol. 29 (2), pp. 90-107, 2010.

[2] M. Redwood, "The application of pilot research on greywater in the middle east north africa region (MENA)", Int. J. Environ. Stud, vol. 65 (1), pp. 109-17, 2008.

[3] M. M. Karpiscak, K. E. Foster and N. Schmidt, "Residential water conservation”, Water Res., vol. 26, pp. 939-948, 1990.

[4] D.A. Okun, "Distributing reclaimed water through dual systems", J. Am. Water Works Assoc., vol. 89 (11), pp. 153-160, 1997.

[5] E. Santala, J. Uotila, G. Zaitsev, R. Alasiurua, R. Tikka and J. Tnegvall, "Microbiological greywater treatment and recycling in an apartment building", in AWT98 Conference on Advanced Waste water Treatment, Recycling and Reuse, 1998, pp. 319-324. 
[6] R. Otterpohl, A. Albold and M. Olgenburg, "Sources control in urban sanitation and waste management: ten systems with reuse of resources", Water Sci. Technol., vol. 39 (5), pp. 153-160, 1999.

[7] E. Eriksson, K. Auffarth, M. Henze and A. Ledin, "Characteristics of grey wastewater", Urban Water, vol. 4, pp. 85-104, 2002.

[8] K. Carden, N. Armitage, K. Winter, O. Sichone and U. Rivett, "Understanding the use and disposal of Greywater in the NonSewered Areas of South Africa", Water Res. Commission Report No. 1524/1/07, Pretoria, 2007.

[9] A. Ledin, E. Eriksson and M. Henze, "Aspects of groundwater recharge using grey wastewater", In: Lens, P., Zeeman, G., Lettinga, G., Eds. Decentralised Sanitation and Reuse: Concepts, systems and implementation, IWA Publishing: London, 2001, pp. 354370 .

[10] S. Finley, S. Barrington and D. Lyew, "Reuse of domestic Greywater for the irrigation of food crop”, Water Air Soil Pollut., vol. 199, pp. 235-245, 2009.

[11] E. Friedler, "Quality of individual domestic greywater streams and its implication for on-site treatment and reuse possibilities", Environ. Technol., vol. 25, pp. 997-1008, 2004.

[12] K. Kotut, V.G. Nganga and F. W. Kariuki, "Physico-chemical and microbial quality of Greywater from various households in homa bay town", Open Environ. Eng. J., vol. 4, pp. 162-169, 2011.

[13] F.W. Kariuki, K. Kotut and V.G. Ngángá, "The potential of a low cost technology for the Greywater treatment”, Open Environ. Eng. J., vol. 4, pp. 32-39, 2011.

[14] E. Madungwe and S. Sakuringwa, "Greywater reuse: a strategy for water demand management in Harare", Phy. Chem. Earth, vol. 32(15-18), pp. 1231-1236, 2007.

[15] S. Toze, "Reuse of effluent water-benefits and risks", Agric. Water Manag., vol. 80, pp. 147-159, 2006.

[16] L. A. Roesner, Y. Qian, M. Criswell, M. Stomberger, and S. Klein, "Long-term effects of landscape irrigation using household graywater: literature review and synthesis," Tech. Rep. 03-CST-18C0, Water and Environment Research Foundation, Alexandria, Va, USA, 2006, [Online] Available at: www. werf.org [Accessed in January $\left.20^{\text {th }} 2012\right]$.

[17] E. Eriksson, K. Auffarth, A.-M. Eilersen, M. Henze and A. Ledin, "Household chemicals and personal care products as sources for xenobiotic organic compounds in grey wastewater", Water S. A., vol. 29(2), pp. 135-146, 2003.

[18] D. Del Porto and C. Steinfeld. What about Graywater, the composting toilet system book. Massachusetts, The Center for Ecological Pollution Prevention (CEPP): Concord, Massachusetts, pp. 167193, 2000.

[19] R. Siegrist, M. Witt and W. C. Boyle, "Characteristics of rural household wastewater", J. Environ. Eng. Div. ASCE, vol. 102(3), pp. 533-548, 1976.

[20] N. Arjun, K. Foxon, N. Rodda, M. Smith, C. Buckley, "Characterisation of wastewater produced by developing communities", In: WISA 2006 Biennial Conference and Exhibition, Durban, 2006.

[21] APHA, Standard Methods for the Examination of Water and Wastewater, $20^{\text {th }}$ ed., American Public Health Association, Washington DC, 1998.

[22] L. A. Richards, "Diagnosis and improvement of saline and alkali soils", Handbook No 60, USDA, Washington DC, pp. 84, 1954.

[23] J. Raude, B. Mutua, M. Chemelil, L. Kraft, and K. Sleytr, "Household greywater treatment for periurban areas of Nakuru Municipal- ity, Kenya”. In: Elke Müllegger, Günter Langergraber, Markus Lechner Eds., Sustainable Sanitation Practice: Vienna, Austria, EcoSan Club15/8, pp. 10-15, 2009.

[24] D. Christova-Boal, R. E. Eden, and S. McFarlane, "An investigation into Greywater reuse for urban residential properties", Desalination, vol. 106, pp. 391-397, 1996.

[25] DWAF, "South African Water Quality Guidelines - Agricultural Use", Irrigation, $2^{\text {nd }}$ ed., vol. 4, pp. 71-165, 1996. [Online] Available at: www.dwaf.gov.za [Accessed in January $20^{\text {th }} 2012$ ].

[26] M. Unkovich, D. Stevens, G. Ying, J. Kelly, "Impacts on crop quality from irrigation with water reclaimed from sewage", pub. Australian Water Conservation and Reuse Research Program, Australia, 2004.

[27] A. Wiel-Shafran, Z. Ronen, N. Weisbrod, E. Adar, A. Gross, "Potential changes in soil properties following irrigation with surfactant-rich greywater", Ecol. Eng., vol. 26, pp. 348-354, 2006.

[28] A. More and S. Diener, "Greywater Management in Low and Middle Income Countries": Review of Different Treatment Systems for Households or Neighbourhoods, pub. Swiss Federal Institute for Aquatic Science and Technology, Dübendorf, Switzerland, 2006.

[29] FAO, "Water quality for agriculture: Irrigation and Drainage paper 29 Rev. 1", Food and Agriculture Organization of the United Nations: Rome, 1985, pp. 174.

[30] R. Kulabako, J. Kinobe, J. Mujunga, S. Olweny, and K, Sleytr, "Greywater use in peri-urban households in Kitgum, Uganda", Sustain. Sanitation Pract., vol. 1, pp. 16-24, 2009.

[31] K. O'H. Murphy, "A scoping study to evaluate the fitness-for-use of greywater in urban and peri-urban agriculture", WRC Report No. K5/1479/1/06, pub. Water Research Commission, Pretoria, South Africa, 2006.

[32] S. Surendran and A. D. Wheatley, "Greywater reclamation for nonpotable reuse", Water Environ. J., vol. 12, pp. 406-413, 1998.

[33] B. Jefferson, A. Palmer, P. Jeffrey, R. Sturtz, S. Judd, "Grey water characterization and its impact on the selection and operation of technologies for urban reuse", Water Sci. Technol., vol. 50(2), pp. 157-164, 2005.

[34] E. Nolde, "Greywater reuse systems for toilet flushing in multi-storey buildings - over ten years experience in Berlin", $U r$ ban Water, vol. 1, pp. 275-284,1999.

[35] F. Gunther, "Wastewater treatment by greywater separation: outline for a biologically based greywater purification plant in Sweden", Ecol. Eng., vol. 15, pp. 139-146, 2000.

[36] B. Vinnerås, Feacal separation and urine diversion for nutrient management of household biodegradable waste and waste water, SLU, Report 244, 2001.

[37] UNEP, WHO, Assessment of Freshwater quality. United Nations Environment Program: USA, 1988, p. 80.

[38] J. M. Shitsama. Heavy metal contaminants in fish, water and sediments in Lake Victoria, Kenya. MPhil thesis, Moi University, pp. 93, 1999.

[39] A.R. Hashem and A.M. Al-Obaid, "Effect of Cadmium on the Growth of Aspergillus flavus and Ulocladium chalmydosporum", Int. J. Exp. Bot., vol. 59 (1/2), pp. 171-175, 1996.

[40] WHO, WHO Guidelines for the Safe Use of Wastewater, Excreta and Greywater, Volume IV, Excreta and Greywater Use in Agriculture. WHO Press: Geneva, 2006. 